\title{
Links between central Greenland stable isotopes, blocking and extreme climate variability over Europe at decadal to multidecadal time scales
}

\author{
N. Rimbu ${ }^{1}$ G. Lohmann ${ }^{1,2} \cdot$ M. Werner ${ }^{1} \cdot$ M. Ionita ${ }^{1,2}$
}

Received: 24 January 2016 / Accepted: 16 September 2016

(C) Springer-Verlag Berlin Heidelberg 2016

\begin{abstract}
The link between central Greenland stable oxygen isotopes, atmospheric blocking frequency and cold temperature extremes at decadal to multidecadal time scales is investigated using observed and proxy data as well as model experiments. A composite analysis reveals that positive stable isotope anomalies in central Greenland are associated with enhanced blocking activity in the Atlantic European region. Several indices of blocking activity in the Atlantic European region are higher correlated with central Greenland stable isotope time series than with the North Atlantic Oscillation indices both in observations and model simulation. Furthermore, the blocking frequency anomaly pattern associated with central Greenland stable isotope variability is similar to the blocking anomaly pattern associated with the Atlantic Multidecadal Oscillation. A composite analysis reveals that stable isotope variations in central Greenland are related to a large-scale pattern in the frequency of extreme low temperature events with significant positive anomalies over Europe and a southwest to northeast dipolar pattern over Asia. During observational period central Greenland isotope records, blocking and extreme temperature indices over Europe show enhanced variability $10-30$ and 50-70 years. Similar quasi-periodicities dominate the spectrum of central Greenland isotope variability during the last millennium. We argue that longterm variations of climate extreme indices over Europe and
\end{abstract}

N. Rimbu

Norel.Rimbu@awi.de

1 Alfred Wegener Institute Helmholtz Centre for Polar and Marine Research, Bussestrasse 24, 27570 Bremerhaven, Germany

2 MARUM - Center for Marine Environmental Sciences, University of Bremen, Bremen, Germany
Asia, as derived from observational data, can be put into a long-term perspective using central Greenland stable isotope ice core records.

Keywords Greenland ice cores · Stable isotopes . Atmospheric blocking $\cdot$ Extreme temperatures

\section{Introduction}

The stable isotope ratios $\left(\delta^{18} \mathrm{O}\right.$ and $\left.\delta \mathrm{D}\right)$ from Greenland ice cores are important archives of present and past climate variability (e.g. Vinther et al. 2010a). The origin of this climate-isotope connection lies in the dependence of both the stable isotopic composition of precipitation and the climate variables on underlying atmospheric physics (Conroy et al. 2013). As there is a relatively high number of stable isotope records available, covering various space and time periods (e.g. Ortega et al. 2014), these relationships are of special significance in paleoclimate research.

From the source regions to Greenland ice cores, the water vapor stable isotope ratios can be modified through fractionation processes. The condensation temperature is the main parameter which controls the $\delta^{18} \mathrm{O}$ in Greenland snowfall. However, the $\delta^{18} \mathrm{O}$ is affected also by changes in evaporation conditions or air mass trajectories (e.g. Masson-Delmotte et al. 2015). Other factors, like thermal inversions, discontinuous sampling, precipitation seasonality, intermittency, deposition effects and changes in the source region could also influence $\delta^{18} \mathrm{O}$ signal in Greenland ice cores (e.g. Ortega et al. 2014). These processes are related to atmospheric circulation variability explaining the correlation between stable isotope records from Greenland ice cores and teleconnection pattern indices (e.g. Vinther et al. 2010a), frequency of weather regimes (Ortega et al. 2014), frequency of daily 
circulation patterns (Rimbu and Lohmann 2010) or atmospheric blocking (Rimbu and Lohmann 2011).

The Arctic region has undergone significant warming in the last decades compared with general warming of the lower-latitudes, a phenomenon called Arctic amplification (e.g. Cohen et al. 2014). This phenomenon was related to significant changes in weather and climate extremes, through a more frequent negative phase of the Arctic/ North Atlantic Oscillation (AO/NAO), a weaker zonal jet with larger meanders or changes in large-scale Rossby waves over Eurasia (Cohen et al. 2014). These possible mechanisms are consistent with an increased frequency of atmospheric blocking in the North Atlantic region and the associated extreme climate events. Decadal to multidecadal variations of several temperature and precipitation extreme indices over Europe during the 1950-2013 period were related to Arctic climate variability (Cohen et al. 2014).

Across the Northern Hemisphere, blocking circulations are observed frequently throughout the year (e.g. Barriopedro et al. 2006). If such circulations are sufficiently strong and persistent they can divert weather systems from their normal path inducing significant climate anomalies, including extreme climatic events (e.g. Silmann et al. 2011). Recent studies identified significant decadal to multidecadal variations in the blocking frequency over Greenland (McLeod and Mote 2016; Hanna et al. 2016) and the whole North Atlantic region (e.g. Häkkinen et al. 2011, Ionita et al., 2016). These variations in blocking frequency were related further with decadal to multidecadal variations in the frequency of extreme climate indices over Europe during observational period (Rimbu et al. 2014). As the observational period is relatively short to have a clear view of such variations, the main goal of this study is to put the blocking and related extreme events variability into a longterm perspective using stable isotope records from central Greenland as well as atmospheric general circulation model experiments. The choice of the central Greenland stable isotope records is motivated by the data availability. Another reason is the existence of a strong relationship between the North Atlantic blocking and central Greenland stable oxygen isotope variability during observational period (Rimbu and Lohmann 2011).

The paper is organized as follows. Data and Methods are presented in Sect. 2. The relationship of central Greenland stable isotope variability and atmospheric blocking variability is discussed in Sect. 3. The connection between central Greenland stable isotope variability and extreme temperatures and the role of atmospheric blocking in explaining these relationships are discussed in Sect. 4. Temporal variability of central Greenland stable isotope anomalies and the possible connection with extreme climatic phenomena are discussed in Sect. 5. A discussion and the main conclusions follow in Sect. 6.

\section{Data and methods}

The main quantities used in this study are three high resolution stable isotope ratios records from central Greenland: GISP2 $\delta^{2} \mathrm{H}$, Crete $\delta^{18} \mathrm{O}$ and GRIP $\delta^{18} \mathrm{O}$ (Fig. 1). The GISP2 deuterium record $\left(72.60^{\circ} \mathrm{N}, 38.50^{\circ} \mathrm{W}\right.$; elevation 3210 m.a.s.l.) covers the period $1300-1985$ with annual resolution. This record was retrieved from the environmental Publishing Network for Geoscientific \& Environmental database PANGAEA (https://doi.pangaea.de/10.1594/ PANGAEA.56088). A detailed description of this record can be found in Barlow et al. (1997). The Crete oxygen isotope record $\left(71.12^{\circ} \mathrm{N} ; 37.32^{\circ} \mathrm{W}\right.$; elevation 3172 m.a.s.l.) covers the period $553 \mathrm{AD}-1973 \mathrm{AD}$ with seasonal resolution (Vinther et al. 2010b). The GRIP stable oxygen record $\left(72.58^{\circ} \mathrm{N} ; 37.64^{\circ} \mathrm{W}\right.$; elevation 3238 m.a.s.l.) covers the period $551 \mathrm{AD}$ to $1979 \mathrm{AD}$ with seasonal resolution (Vinther et al. 2010c). Crete and GRIP records were downloaded also from the PANGAEA database (https://www. pangaea.de). Although the winter $\delta^{18} \mathrm{O}$ values correspond to the November to March interval (Vinther et al. 2010a) we look for the associated atmospheric circulation patterns for December, January and February (DJF). This choice is

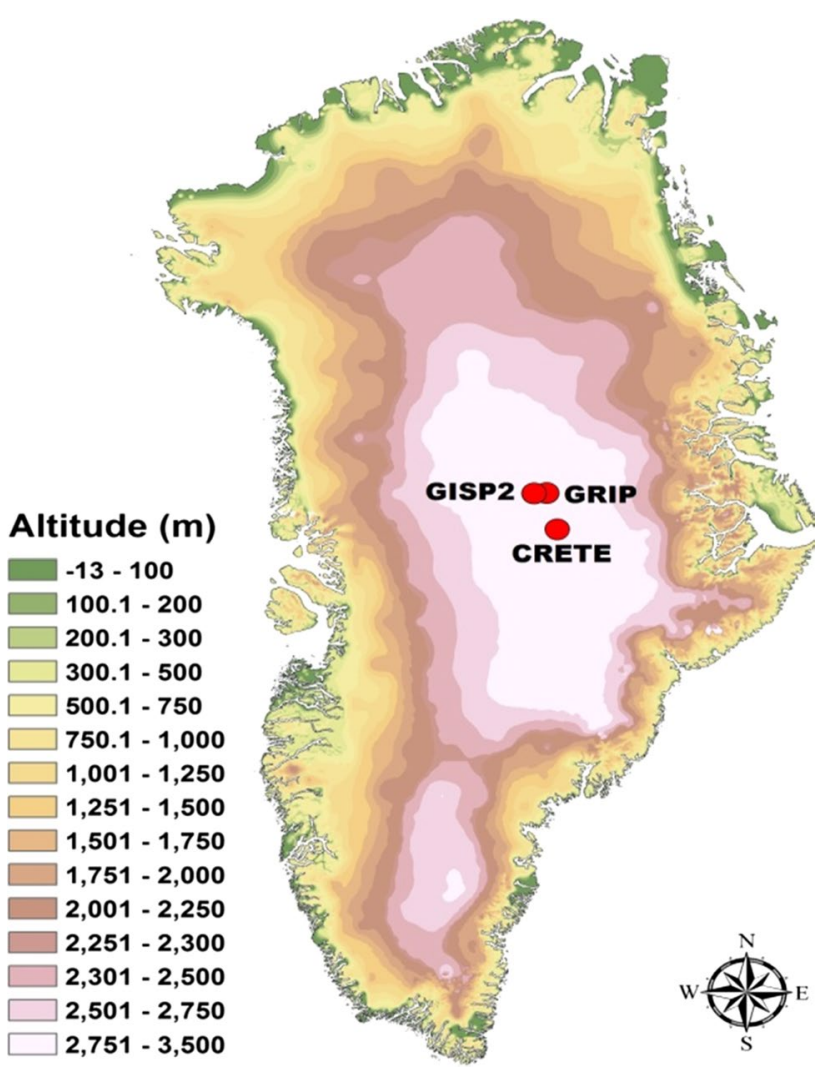

Fig. 1 Map of Greenland showing the position of ice core records used to establish central Greenland stable isotope variability during 1300-1973 
motivated by the fact that the patterns of two-dimensional blocking indices used in this study are validated only for DJF. However, no significant alteration of the results presented here is obtained when the analysis is extended to November-March period.

To increase the signal to noise ratio we performed an Empirical Orthogonal Function (EOF) analysis (e.g. von Storch and Zwiers 1999) on the normalized values of the winter GRIP and Crete and annual GISP2 records over the common period 1300-1973 (684 years). The first principal component (PC1) of these records is used to identify the blocking and corresponding extreme phenomena patterns associated with central Greenland isotope variability.

In this study the outputs of ECHAM5-wiso simulation (Werner et al. 2011; Butzin et al. 2014) were used to identify the atmospheric circulation patterns associated with central Greenland stable isotope variability. ECHAM5wiso is the isotope-enabled version of the atmospheric general circulation model ECHAM5 (e.g. Roeckner et al. 2006). Details related to the stable isotope module of ECHAM5-wiso model can be found in Werner et al. (2011), Langebroek et al. (2011) and Butzin et al. (2014). A horizontal model resolution of T106 in spectral space (horizontal grid size of approximately $1.125^{\circ} \times 1.125^{\circ}$ ), and a vertical resolution of 31 levels on hybrid sigmapressure coordinates were considered in this ECHAM5wiso simulation. To ensure a more realistic simulation of present-day climate variability, the model was forced with prescribed yearly values of present-day insolation and greenhouse gas concentrations (IPCC 2000) as well as with monthly varying fields of sea-surface temperatures and sea-ice concentrations according to ERA-Interim reanalysis data (Dee et al. 2011). Furthermore, the dynamic-thermodynamic state of the ECHAM5 model is constrained to reanalysis data by an implicit nudging technique. The modeled fields of surface pressure, temperature, divergence and vorticity are relaxed to the corresponding ERA-Interim reanalysis fields. The performed simulation covers the period September 1957 until July 2013. Here we regard the first 28 months as model spin-up and analyze the simulated winter $\delta^{18} \mathrm{O}$ during a 53 -year period between $1960 / 61$ and $2012 / 13$. The winter mean $\delta^{18} \mathrm{O}$ was calculated as a precipitation weighted average of daily $\delta^{18} \mathrm{O}$ for December, January and February.

The observed blocking frequency is calculated based on the daily $500 \mathrm{hPa}$ geopotential height (Z500) from the twentieth Century Reanalysis database, version 2 (Compo et al. 2011) (available at http://www.esrl.noaa.gov/psd/ data/gridded/data.20thC_ReanV2.html). The analysis is limited to the period 1901-1973 when both ice cores and extreme climate indices are available. We calculate both one-dimensional (1D) and two-dimensional (2D) blocking indicators. The 1D is based on the classical Tibaldi-Molteni
(TM) index (Tibaldi and Molteni 1990). The 2D blocking indicator is based on the Scherrer et al. (2006) algorithm. This 2D index is based on evaluation of blocking conditions in each grid-point and goes beyond the classical onedimensional TM index (e.g. Davini et al. 2012). The same algorithms were used to calculate the blocking frequency in the ECHAM5-wiso model simulation over the period 1960/61-2012/2013 (53 winters).

To analyze the relationship between Greenland ice cores and extreme climate events over Europe we use five indices of extreme temperatures: TN10p, TXx, TNx, TXn and $\mathrm{TNn}$, respectively. TN10p is an index measuring the percentage of time with daily minimum temperatures lower than the 10th percentile of minimum temperatures calculated for each calendar day (with reference to the climatological norm) using a running 5-day window. This is a measure of the percentage of low temperature nights (cool nights) in a winter. To check the consistency of the patterns we used another four extreme temperature indices, which are the maximum value of the maximum (minimum) $(\operatorname{TXx}(\operatorname{TNx}))$ and the minimum value of the maximum (minimum) (TXn(TNn)) daily temperature of each considered winter. Definition and details about these and other extreme climate indices can be found in Karl et al. (1999). These indices were extracted from the global land-based gridded data set of climate extreme indices HadEX2 (Donat et al. 2013). This data set covers the global land with a $3.75^{\circ} \times 2.5^{\circ}$ resolution over the period 1901-2010 (available at http://www.metoffice.gov.uk/hadobs/hadex2). Additionally, we used station based extreme temperature indices developed within the framework of the European Climate Assessment \& Dataset project (ECA\&D) (e.g. Haylock et al. 2008) (available at http://eca.knmi.nl/). We selected only those stations which cover the period 1901-2010 having more than $70 \%$ available data.

The fingerprints of the North Atlantic Oscillation (NAO) on central Greenland stable isotope variability are investigated using the instrumental index of the NAO defined as the standard difference in sea level pressure (SLP) between Gibraltar and Iceland (Jones et al. 1997) (available at http:// www.cru.uea.ac.uk/cru/data/) as well as station and PC based NAO indices (hereafter referred to as NAO-S and NAO-PC respectively) defined by Hurrell et al. (2003) (available at https://climatedataguide.ucar.edu/climatedata/). The modeled NAO index is calculated as the PC1 of the linearly detrended and normalized winter SLP from the North Atlantic region $\left(90^{\circ} \mathrm{W}-40^{\circ} \mathrm{E} ; 20^{\circ} \mathrm{N}-80^{\circ} \mathrm{N}\right)$. Furthermore, we used also the PCs associated with the dominant patterns of blocking in the North Atlantic region during the 1871-2010 period, described in Rimbu et al. (2014). The time series of the Atlantic Multidecadal Oscillation (AMO) index, defined as the area weighted average of the North Atlantic $\left(0-70^{\circ} \mathrm{N}\right)$ sea surface temperature anomalies, was 
downloaded from the Earth System Research Laboratory (ESRL) web page (http://www.esrl.noaa.gov/psd/data/correlation/amon.us.long.data).

Through composite analysis, we identify the blocking and extreme temperature anomaly patterns associated with central Greenland stable isotope anomalies. The anomaly maps corresponding to winters characterized by high $(>+0.75$ standard deviation) and low $(<-0.75$ standard deviation) values of a certain index are averaged. The difference between these averaged maps will be referred to as composite maps. The statistical significance of the composite or correlation maps is calculated using a simple $t$ test (e.g. von Storch and Zwiers 1999). Temporal periodic signals in the time series of stable isotope from central Greenland ice cores are identified using wavelet analysis (e.g. Torrence and Compo 1998). Statistical significance is determined against a red noise null hypothesis using a Chisquare test.

\section{Stable isotope and blocking variability}

The stable isotopes time series (Fig. 2) shows pronounced interannual to multidecadal variations during the last millennium. The variability of these records during the last decades is not unusual in the perspective of last millennium
Fig. 2 Original (dotted) and 5 -year running mean (solid) time series of a annual GISP2 deuterium, $\mathbf{b}$ winter Crete $\delta^{18} \mathrm{O}$ and $\mathbf{c}$ winter GRIP $\delta^{18} \mathrm{O}$ (a)

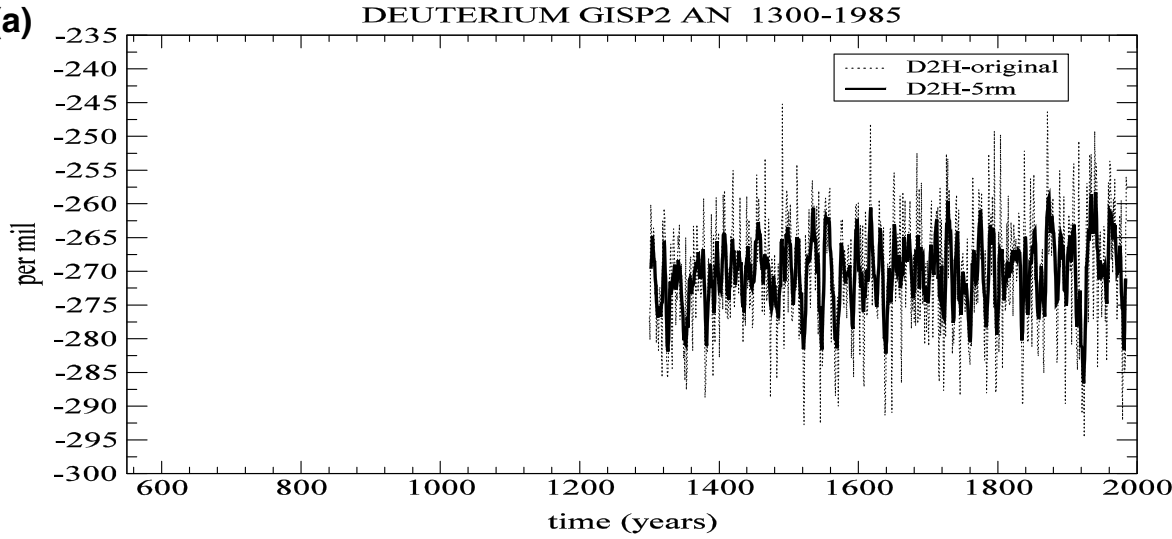

(b)

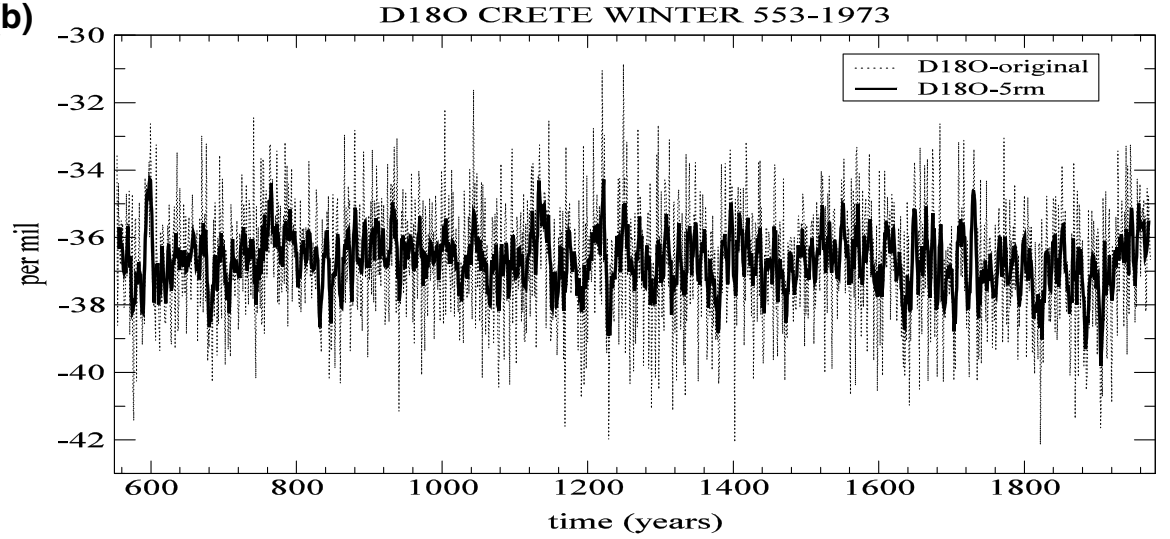

(c)

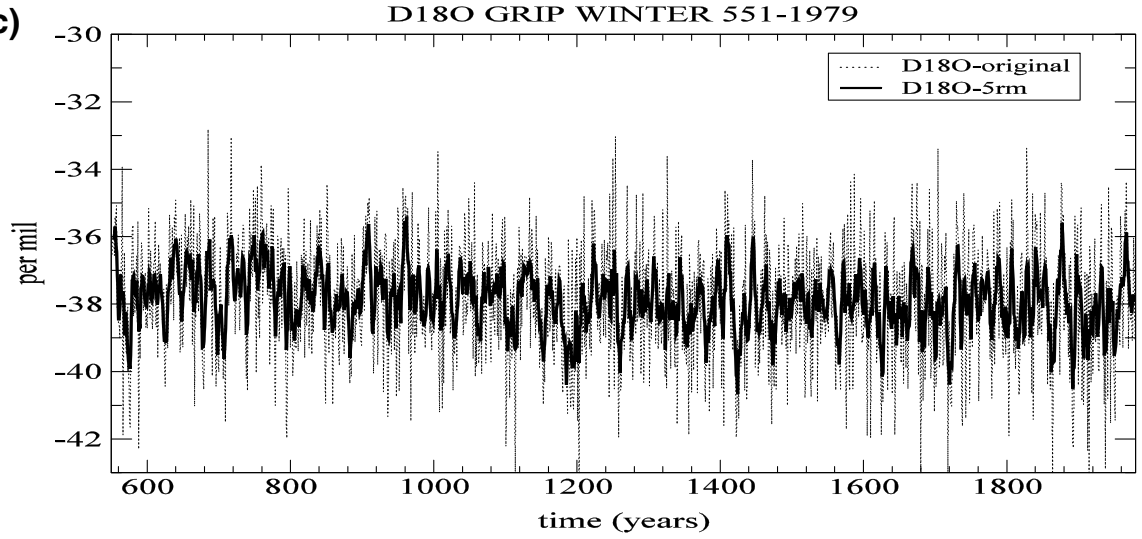


variability. Over the common period, which is $1300-1973$, the three time series are positively correlated each other. At decadal time scales (5-year running mean) the correlation coefficients of GISP2 with Crete and GRIP time series are +0.14 and +0.29 respectively, while GRIP and Crete time series are correlated at +0.30 level. Consistent with this correlation structure, the first EOF of the three normalized time series, which describes $48 \%$ variance, has a monopolar structure (loadings are 0.54, 0.64 and 0.53 for Crete, GRIP and GISP2 respectively). The corresponding principal component (PC1) is used further as an index of observed central Greenland stable isotopes variability at decadal to multidecadal time scales over the 1300-1973 period.

For the ECHAM5-wiso, the winter $\delta^{18} \mathrm{O}$ climatology (Fig. 3) shows pronounced negative values in central Greenland, consistent with $\delta^{18} \mathrm{O}$ climatology derived from seasonal resolution Greenland ice cores (e.g. Vinther et al. 2010a). We define a central Greenland $\delta^{18} \mathrm{O}$ index by averaging the simulated winter $\delta^{18} \mathrm{O}$ within the $\left(39^{\circ} \mathrm{W}-36^{\circ} \mathrm{W}\right.$; $70^{\circ} \mathrm{N}-73^{\circ} \mathrm{N}$ ) area (Fig. 3). The selected ice cores (Fig. 1) are located within this region. The mean value of this index over the period $1961-1973$ is $-34.55 \%$, which is higher than the average $\delta^{18} \mathrm{O}$ from Crete over the same period, which is $-35.90 \%$. The average $\delta^{18} \mathrm{O}$ during the 1961-1979 period is higher in the simulation $(-34.24 \%$ o) compared with the GRIP record $(-37.40 \%$ ). To our knowledge, no evaluation of ECHAM5-wiso winter $\delta^{18} \mathrm{O}$ simulation has been published yet. However, a previous version of this model, i.e. ECHAM4-wiso, shows a warm bias over the Greenland ice sheet, probably associated with model biases for surface temperature inversion or albedo

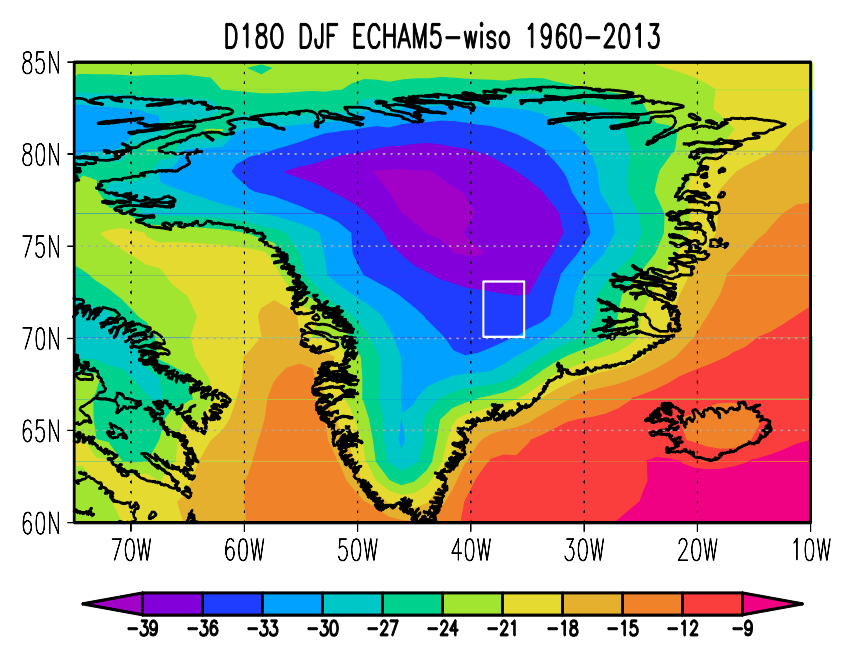

Fig. 3 Winter (DJF) mean $\delta^{18} \mathrm{O}$ over Greenland for the period 1960/61-2012/13 as simulated by the ECHAM5-wiso model. Units $\%$. The box represents the region used to define a central Greenland $\delta^{18} \mathrm{O}$ index (see text for details)
(Werner and Heimann 2002). This warm bias is consistent with more positive central Greenland $\delta^{18} \mathrm{O}$ in ECHAM5wiso simulation compared with observations (Fig. 4).

Both the simulated $\delta^{18} \mathrm{O}$ index and the PC1 of stable isotope ice cores show pronounced decadal variations over 1960-2013 and 1900-1973 periods (Fig. 4). The period covered by both the simulated $\delta^{18} \mathrm{O}$ index as well as the ice cores PC1 is relatively short, i.e. 1960-1973. Small variations from 1960 to 1968 followed by pronounced negative linear trends are recorded both in the ice cores PC1 and simulated $\delta^{18} \mathrm{O}$ index (Fig. 4). Therefore, the observed decadal variations in the central Greenland stable isotopes are quite well reproduced in this ECHAM5-wiso model simulation during this short period, i.e. 1960-1973. The central Greenland stable isotope variability, as captured by ice cores PC1 shows strong variability at time scales of 20-30 years with minima (maxima) in 1920s and 1950s (1900s, 1930s and 1960s) (Fig. 4).

The 2D blocking climatology based on daily Z500 fields from the 20CR reanalysis (Fig. 5a) is very similar to the corresponding ECHAM5-wiso blocking climatology (Fig. 5b). Both maps indicate relatively high blocking frequency in a region that stretches from Davis Strait/ Labrador Sea to Scandinavia as well as another region that extends from the Azores to southern Scandinavia. High frequency blocking centers are founded over southeastern Greenland, North Sea and Ural mountain region (Fig. 5). Similar results were obtained in previous studies (e.g. Scherrer et al. 2006; Rimbu et al. 2014). The differences between absolute values of blocking frequency in 20CR (Fig. 5a) and ECHAM5-wiso simulation (Fig. 5b) could

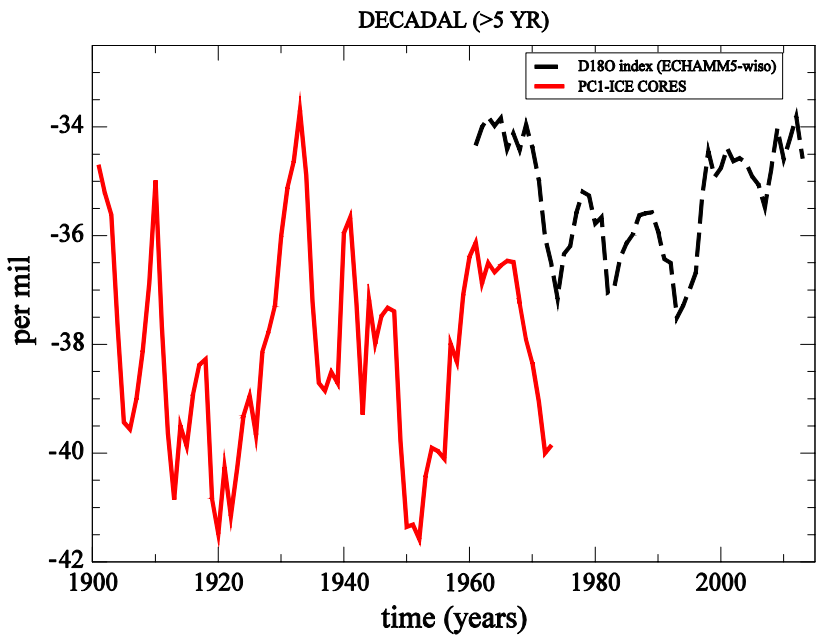

Fig. 4 Time series of central Greenland $\delta^{18} \mathrm{O}$ index simulated with ECHAM5-wiso (dashed) and PC1 of stable isotope records from Crete, GRIP and GISP2 ice cores (solid). The PC1 was scaled to have the same mean and standard deviation as the GRIP record. Data are linear detrended and filtered with a 5-year running mean 
(a)

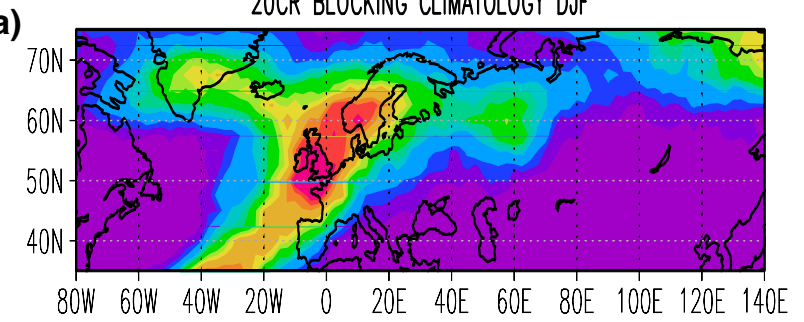

(b) ECHAM5-wiso BLOCKING CLIMATOLOGY DJF
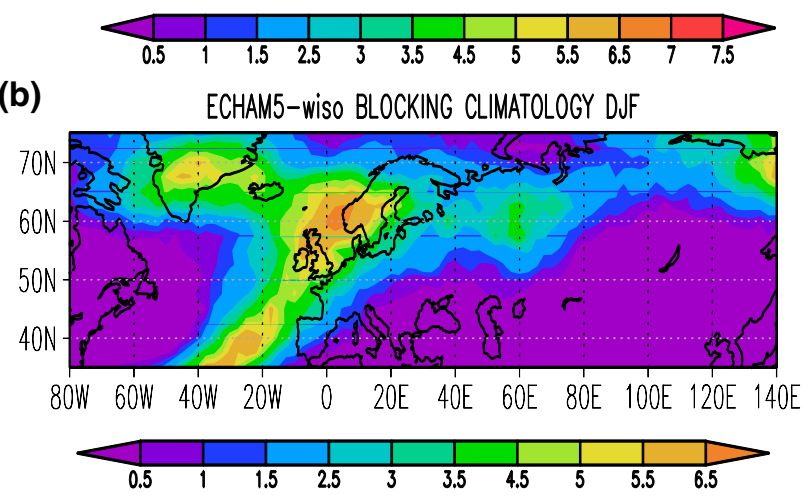

(c) BLOCKING FREQUENCY DJF CLIMATOLOGY

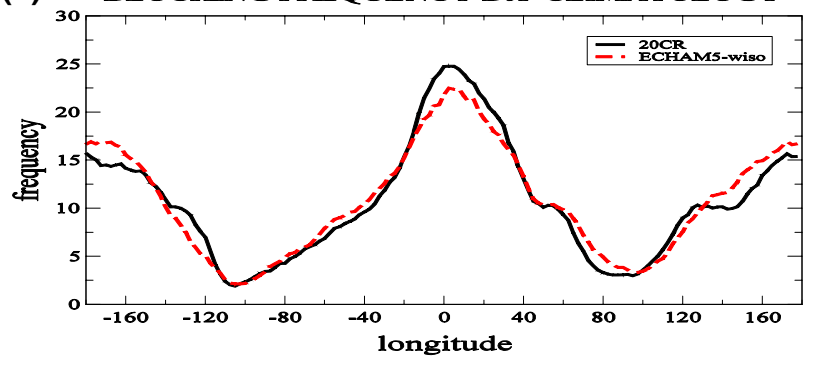

Fig. 5 2D blocking frequency climatology for a observations (20CR reanalysis) and b ECHAM5-wiso model simulation. c 1D blocking frequency climatology for observations (solid) and ECHAM5-wiso simulation (dashed). Units are \% of blocked days from total number of winter days of the period 1960/61-2012/13

be related to model characteristics as well as to blocking characteristics in ERA-Interim reanalysis used as nudging fields in this ECHAM5-wiso simulation. The 1D blocking climatology in 20CR and ECHAM5-wiso simulation (Fig. 5c) capture well the maxima of blocking frequencies in the Atlantic and Pacific regions with frequency similar to that presented in previous observational studies (e.g. Barriopedro et al. 2006).

The 2D blocking composite map associated with the central Greenland stable isotope ice core variability (Fig. 6a) shows a pattern similar to that associated to the Atlantic Multidecadal Oscillation (AMO) (Häkkinen et al. 2011). Positive (negative) stable isotope anomalies in central Greenland are associated with positive (negative) blocking frequency anomalies in a region stretching from southern Greenland to central Europe as well as with negative (positive) blocking frequency anomalies over northeastern Europe (Fig. 6a).

\section{(a) BLOCKING FREQUENCY HIGH-LOW PC1 ICE CORES}

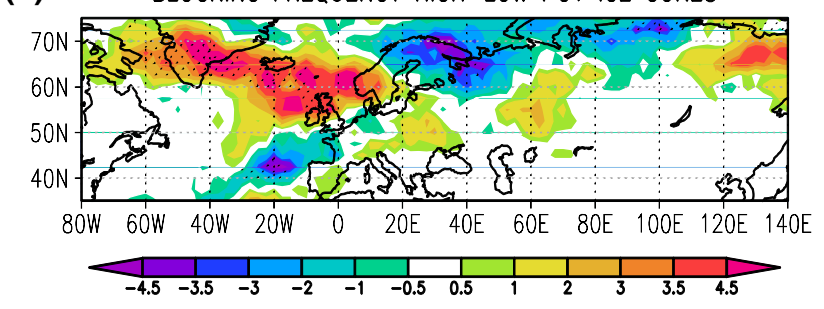

(b)
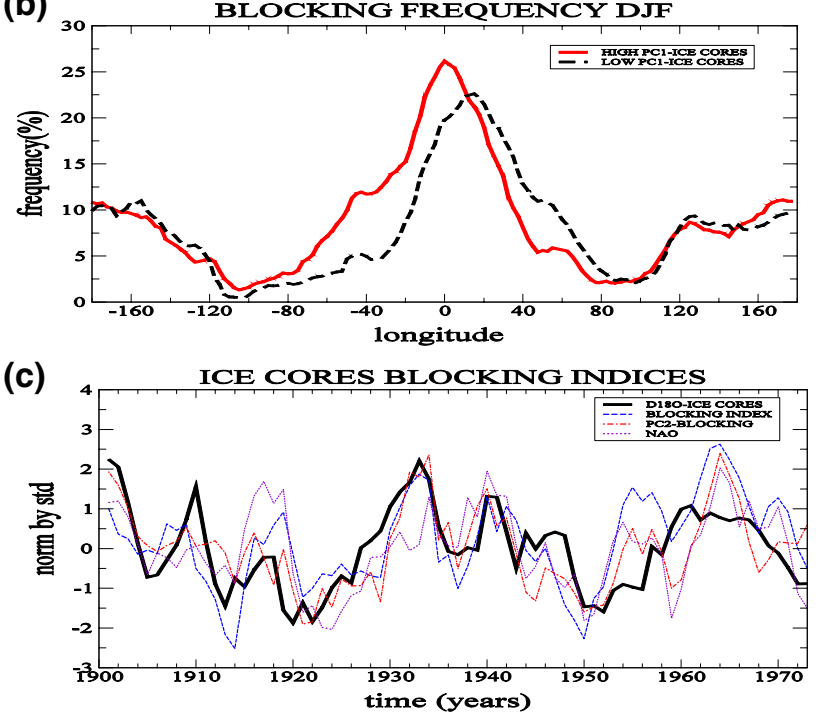

Fig. 6 a The composite map of 2D blocking frequency associated to PC1 of stable isotope records from central Greenland. The regions where the anomalies are significant at $90 \%$ level are hatched. b The 1D blocking frequency corresponding to high (solid) and low (dashed) values of PC1 of central Greenland stable isotope time series c PC1 of stable isotope time series (solid), blocking frequency index (dashed), PC2 of second pattern of blocking variability (dotteddashed) and the NAO index multiplied with minus one (dotted). Data are linear detrended and filtered with a 5-year running mean

The corresponding 1D composite maps (Fig. 6b) shows enhanced blocking activity in the Atlantic European sector $\left(80^{\circ} \mathrm{W}-20^{\circ} \mathrm{E}\right)$ for positive stable isotope anomalies in the central Greenland, consistent with the 2D blocking pattern composite (Fig. 6a). Note the significant differences between both 2D and 1D patterns associated with central Greenland isotope variability (Fig. 6a, b) and the corresponding NAO blocking patterns (Barriopedro et al. 2006; Scherrer et al. 2006). Based on the composite map represented in Fig. $6 \mathrm{~b}$, we define a blocking index as the number of days in a winter when the sector $\left(80^{\circ} \mathrm{W}-20^{\circ} \mathrm{E}\right)$ was blocked. This sector is considered to be blocked if TM blocking conditions are satisfied for at least five consecutive longitudes within it for at least five consecutive days. This blocking index is significantly positively correlated with $\mathrm{PC} 1$ of central Greenland ice cores $(\mathrm{r}=+0.55)$ (Fig. 6c). The ice core $\mathrm{PC} 1$ is negatively correlated with NAO-CRU ( $r=-0.46)$, NAO-PC $(r=-0.39)$ as well as with NAO-S $(r=-0.41)$. The ice core $\mathrm{PC} 1$ is best correlated 
$(\mathrm{r}=+0.64)$ with PC2 of the North Atlantic blocking variability (Fig. 6c). This is consistent with strongly resemblance between blocking anomaly pattern associated with central Greenland stable isotope variability (Fig. 6a) and second pattern of blocking variability in this region (Rimbu et al. 2014; their Fig. 4a). Multidecadal variations of both ice core PC1 and blocking indices shows strong variations at 20-30 years time scales with minima in 1920s and 1950s and maxima 1900s, 1930s and 1960s (Fig. 6c).

The ECHAM5-wiso simulated 2D blocking pattern associated with the central Greenland $\delta^{18} \mathrm{O}$ index shows positive anomalies in a region stretching from southern Greenland to western Europe (Fig. 7a). However, positive

(a) BLOCKING FREQUENCY HIGH-LOW D180 INDEX ECHAM5-wiso

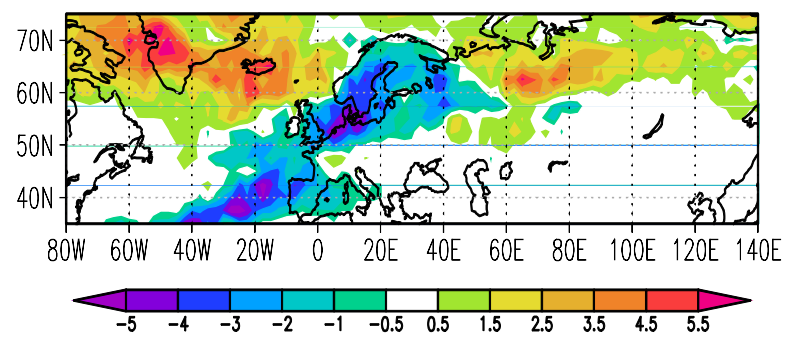

(b) BLOCKING FREQUENCY DJF ECHAM5-wiso

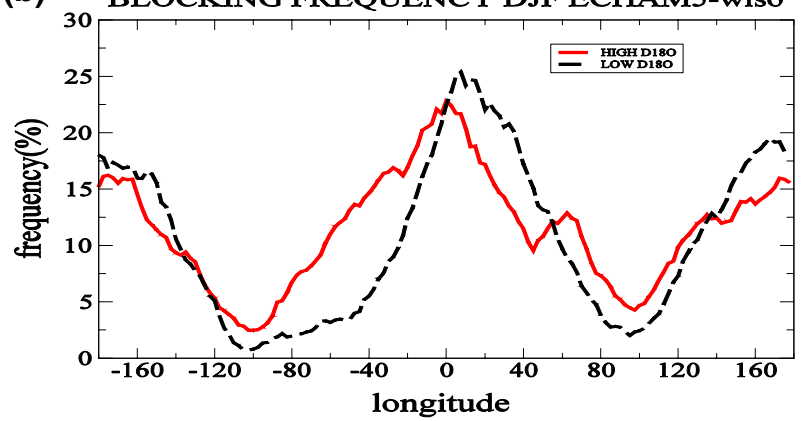

(c) D18O BLOCKING NAO INDICES ECHAM5-wiso

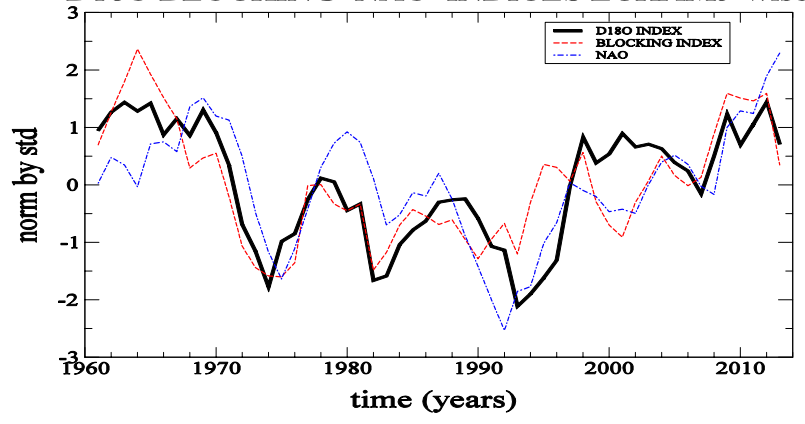

Fig. 7 a The composite map of 2D blocking frequency associated with central Greenland $\delta^{18} \mathrm{O}$ index simulated by the ECHAM5-wiso. The regions where the anomalies are significant at $90 \%$ level are hatched. b The 1D blocking frequency corresponding to high (solid) and low (dashed) values of simulated central Greenland $\delta^{18} \mathrm{O}$ index. c Simulated central Greenland $\delta^{18} \mathrm{O}$ index (solid) and blocking frequency index (dashed) and the NAO index multiplied with minus one (dotted-dashed). Period is 1960-2013. Data are linear detrended and filtered with a 5-year running mean blocking anomalies do not extend to central Europe as in the observed pattern (Fig. 6a). The increase in the 1D blocking frequency index in the Atlantic region $\left(80^{\circ} \mathrm{W}-0\right)$ during positive $\delta^{18} \mathrm{O}$ anomalies compared with negative $\delta^{18} \mathrm{O}$ anomalies in central Greenland is clearly shown by the model simulation (Fig. 7b), consistent with the 2D blocking pattern (Fig. 7a). Both the 2D as well as the 1D simulated blocking anomaly patterns (Fig. 7a, b) strongly resembles the corresponding NAO blocking related patterns. Based on the composite map represented in Fig. 7b, we calculate the frequency of blocking in the sector $\left(80^{\circ} \mathrm{W}-0\right)$. The simulated blocking index (Fig. $7 \mathrm{c}$ ) shows decadal variations similar to $\delta^{18} \mathrm{O}$ index and the simulated NAO index (Fig. 7c). The $\delta^{18} \mathrm{O}$ index is significantly positively correlated $(\mathrm{r}=+0.76)$ with blocking index and significantly negatively correlated $(\mathrm{r}=-0.69)$ with simulated NAO index. The correlation decreases to +0.60 if the blocking index is evaluated for $\left(80^{\circ} \mathrm{W}-20^{\circ} \mathrm{E}\right)$ as in the case of observations. Correlation coefficients of similar magnitudes between the NAO index and $\delta^{18} \mathrm{O}$ over Europe in the ECHAM5-wiso simulations are reported by Butzin et al. (2014) and more recently by Comas-Bru et al. (2016).

To better assess the relationship between central Greenland stable isotope and blocking variability at AMO time scales we filtered out the variability at time scales smaller than 40 years both from ice core $\mathrm{PC} 1$, simulated $\delta^{18} \mathrm{O}$ index and blocking PC2. The ice core PC1 and simulated central Greenland $\delta^{18} \mathrm{O}$ index follow variations similar to the AMO index over the period 1901-2013 (Fig. 8). The phase

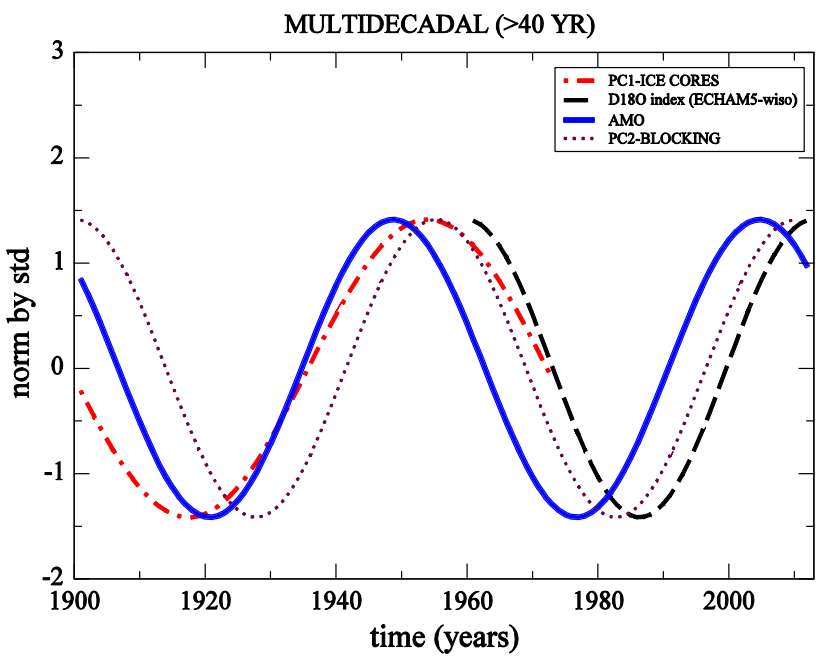

Fig. 8 Multidecadal (time scales longer than 40 years) variations of ice core PC1 (dotted-dashed), simulated $\delta^{18} \mathrm{O}$ index (dashed), PC2 of blocking (dotted) and AMO index (solid). The mismatch between central Greenland $\delta^{18} \mathrm{O}$ time series, AMO and blocking indices could be related to strong filtering applied to these relatively short time series 
differences in the 1950s (1980s) AMO maximum (minimum) could be related to the strong filtering of these relatively short time series. The AMO index leads the blocking PC2 with 5-10 years, consistent with previous studies (Rimbu et al. 2014).

\section{Relationship with extreme temperatures}

We investigate first the extreme temperature indices and atmospheric circulation anomaly patterns associated with central Greenland isotope anomalies using winter resolution data. The composite map of winter TN10p indices associated with PC1 of stable isotope ice cores from central Greenland (Fig. 9a) shows coherent large-scale structures. Significant positive anomalies are recorded over central and southern Europe $\left(10^{\circ} \mathrm{E}-40^{\circ} \mathrm{E} ; 40^{\circ} \mathrm{N}-55^{\circ} \mathrm{N}\right)$ and over a region stretching from Turkey to western China $\left(40^{\circ} \mathrm{E}-80^{\circ} \mathrm{E} ; 35^{\circ} \mathrm{N}-45^{\circ} \mathrm{N}\right)$ while negative correlations prevail over a large part of eastern Russia $\left(70^{\circ} \mathrm{E}-120^{\circ} \mathrm{E}\right.$; $\left.45^{\circ} \mathrm{N}-70^{\circ} \mathrm{N}\right)$. The corresponding pattern of $500 \mathrm{hPa}$ atmospheric circulation (Fig. 9b) is consistent with the extreme

(a)

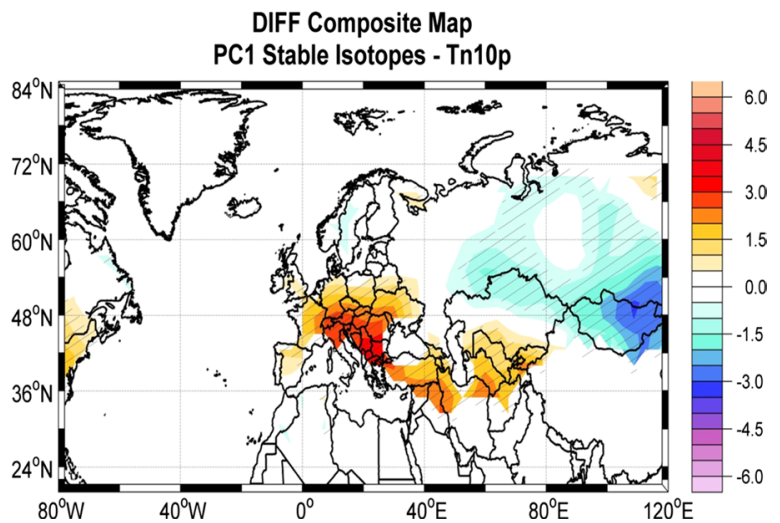

(b)

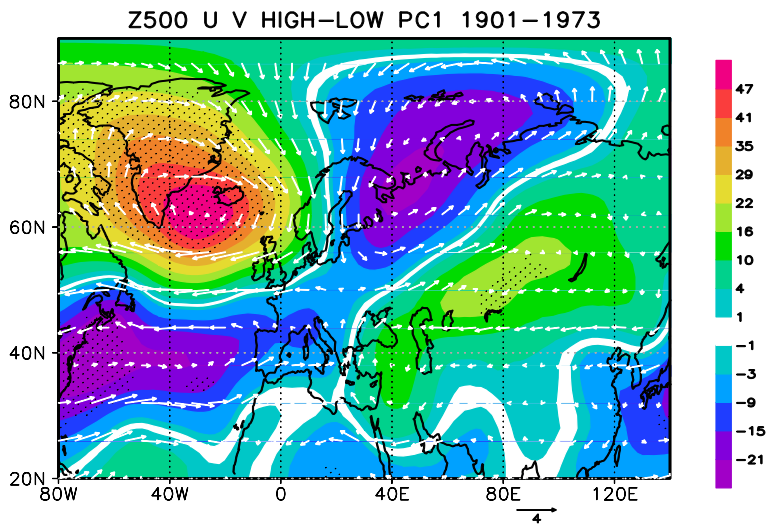

Fig. 9 a Composite map of TN10p indices associated with ice core PC1. b As in a but for $500 \mathrm{hPa}$ geopotential height (color) and wind (arrows). The regions where the anomalies are significant at $90 \%$ level are hatched. Period is 1901-1973. Units: days and $\mathrm{m}$ and m/s respectively temperature pattern represented in Fig. 9a. Enhanced cold air advection over central and southern Europe during high blocking activity in the Atlantic-European region is consistent with a high frequency of the cold events in these regions. Also the anomalous warm and cold advection associated with the anomalous high pressure center from central Asia (Fig. 9b) is consistent with the southwest to northeast dipole pattern in the TN10p indices over Asia (Fig. 9a). A similar wave-train from Atlantic to southern Asia is associated with the second pattern of blocking variability in the North Atlantic region (Rimbu et al. 2014), which is significantly positively correlated with ice core PC1 (Fig. 6c). The Z500 pattern associated with central Greenland simulated $\delta^{18} \mathrm{O}$ (not shown) projects strongly on the NAO. However, some characteristics of the observed atmospheric circulation pattern are captured in the simulation.

To better assess and confirm the patterns based on seasonal resolution data, we look for the synoptic-scale patterns associated with extreme positive daily anomalies of the central Greenland $\delta^{18} \mathrm{O}$ index in the ECHAM5wiso model simulation. An extreme positive $\delta^{18} \mathrm{O}$ event is defined as the number of consecutive days with central

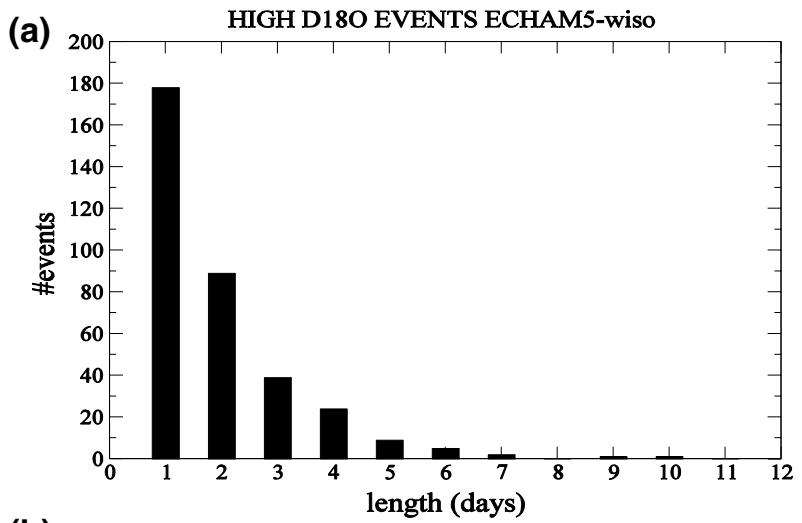

(b)

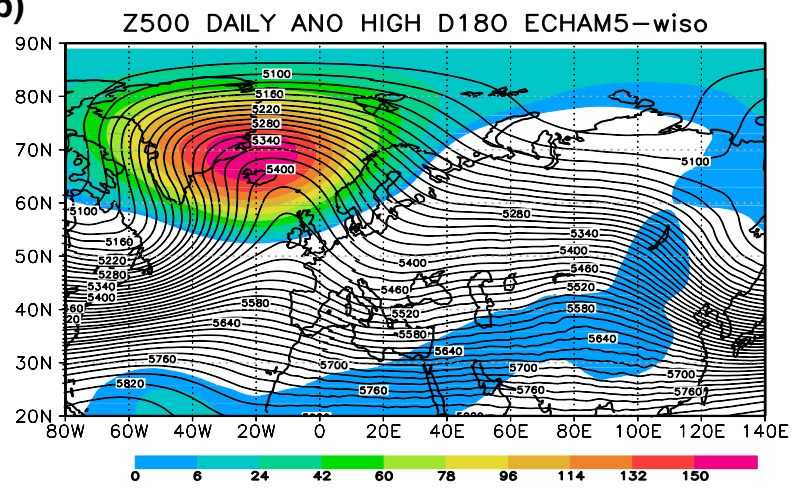

Fig. 10 a Frequency of extreme high $\delta^{18} \mathrm{O}$ events (consecutive values of daily $\delta^{18} \mathrm{O}$ index $>1$ standard deviation) function of their duration. b Average daily Z500 (contour) and positive Z500 anomalies (shaded) when the daily central Greenland $\delta^{18} \mathrm{O}$ index was higher than one standard deviation. Both $\delta^{18} \mathrm{O}$ and Z500 fields are from ECHAM5-wiso simulation for the period 1960-2013. Units: $\mathrm{m}$ 
Greenland $\delta^{18} \mathrm{O}$ index higher than one standard deviation. No filter was applied to daily $\delta^{18} \mathrm{O}$ index prior to this analysis. Such events have different durations varying between 1 day and 10 days (Fig. 10a). The average map of daily Z500 field simulated with ECHAM5-wiso for all high $\delta^{18} \mathrm{O}$ events (Fig. 10b) shows a pronounced ridge in the North Atlantic, which is indicative of enhanced blocking in the region. A less pronounced ridge is recorded downstream over Asia (Fig. 10b). These ridges are compatible with a high frequency of cold events over Europe as well as with the dipole pattern in the frequency of cold events over Asia (Fig. 9a).

The longest high $\delta^{18} \mathrm{O}$ event in the ECHAM5-wiso simulation, which occurred during 19-28 February, 2005, lasted 10 days (Fig. 10a). It is interesting to see the atmospheric circulation associated with this particular event. During 19 February, a pronounced ridge appears in the North Atlantic (Fig. 11a) which is associated with advection of warm and (a)

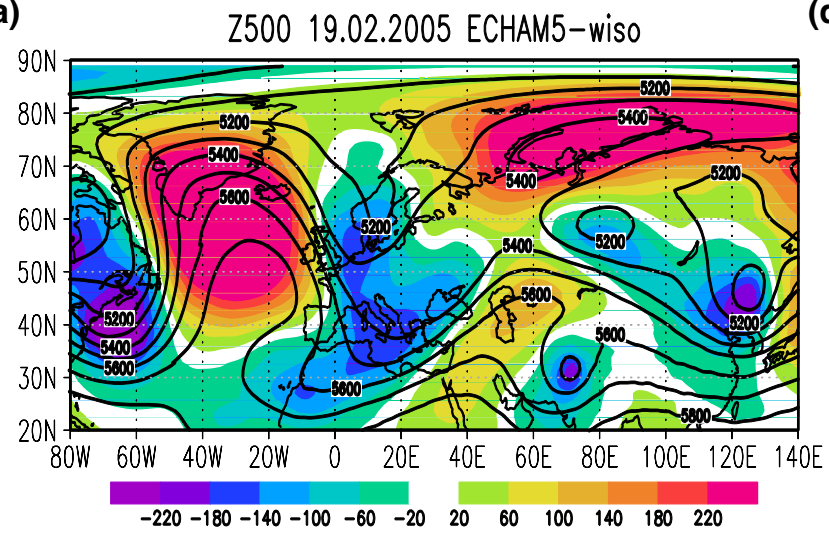

(b)

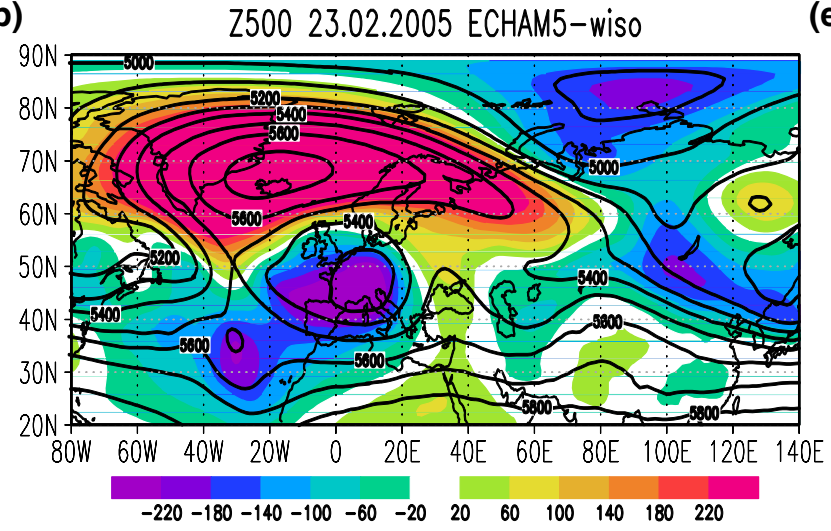

(d)

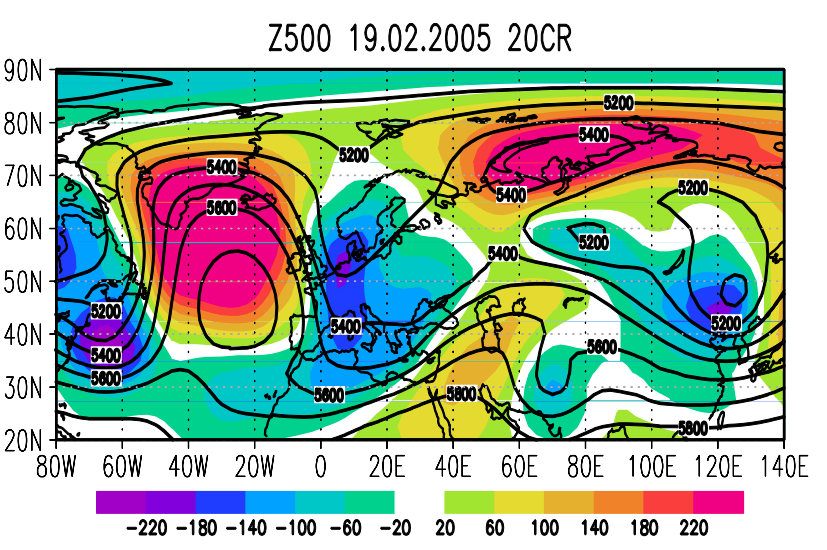

(e)

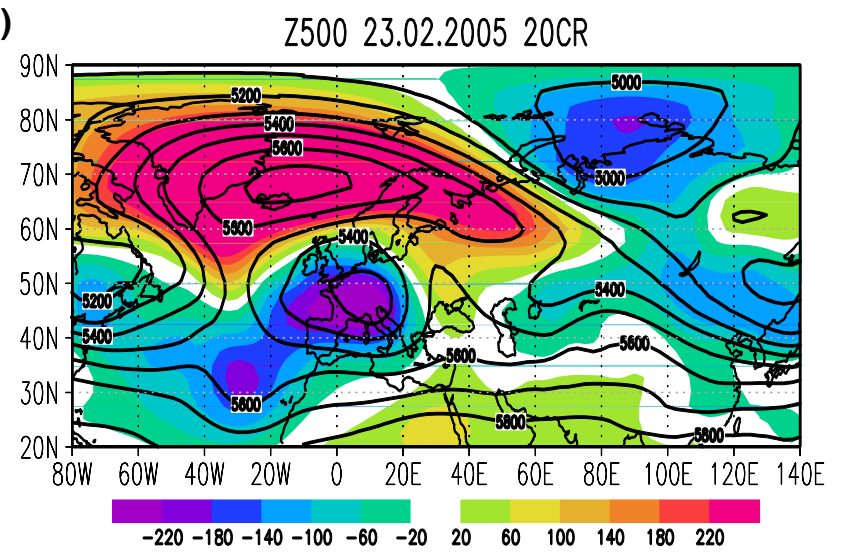

(f)

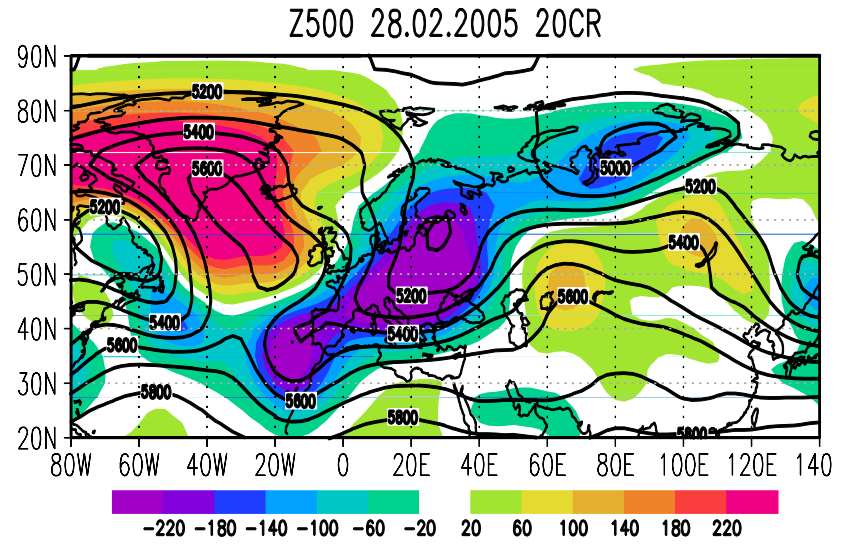

Fig. 11 a-c Z500 (contour) and Z500 anomaly (color) maps for 19, 23 and 28 February 2005 from ECHAM5-wiso simulation. d-f as in a-c but for the 20CR data. Units $\mathrm{m}$ 
moist air towards Greenland. This ridge breaks cyclonically into a high pressure system centered southeast of Greenland on 23 February (Fig. 11b) A less pronounced ridge appears over central Asia (Fig. 11a-c). Similar structures appear in the corresponding 20CR Z500 maps (Fig. 11df). This event resembles a typical cyclonic Rossby wave breaking event in the North Atlantic region as presented in Liu and Barnes (2015). Cyclonic and anticyclonic Rossby wave breaking events are responsible for extreme moisture transport into the Arctic region (Liu and Barnes 2015) and could be related to extreme $\delta^{18} \mathrm{O}$ events in Greenland precipitation. The structure of the circulation for this particular $\delta^{18} \mathrm{O}$ event in central Greenland is consistent with a more meandering polar jet, a circulation structure that appears more often during the recent decades connected to the Arctic amplification phenomena (Cohen et al. 2014). Therefore, the composite structure associated with high positive anomalies of $\delta^{18} \mathrm{O}$ in central Greenland (Fig. 9b) is consistent with increased frequency of synoptic scale circulations like those represented in Fig. 11.

The composite maps of absolute minimum (TNn) (Fig. 12a), maximum of minimum (TNx) (Fig. 12c), minimum of maximum (TXn) (Fig. 12b) and absolute maximum (TXx) (Fig. 12d) values of daily winter temperatures, associated with ice core PC1, show anomalies compatible with the TN10p pattern (Fig. 9a). All indices show significant negative anomalies over Europe, consistent with increased frequency of extreme cold events over this region (Fig. 9a). However, the dipolar structure over Asia is less clearly defined for these extreme indices compared with TN10p (Fig. 9a). This is due to the fact that TN10p indices, which are based on percentile thresholds, are less noisy compared with TNn, TNx, TXn and TXx indices, which represents particular measured temperatures.

\section{Temporal variability}

The composite maps represented in Fig. 12 show that significant negative (positive) anomalies of extreme temperatures over central and southern Europe are associated with positive (negative) $\delta^{18} \mathrm{O}$ anomalies in central Greenland ice cores. To check the robustness of this result, we performed a similar analysis, but using station based extreme climatic (a)

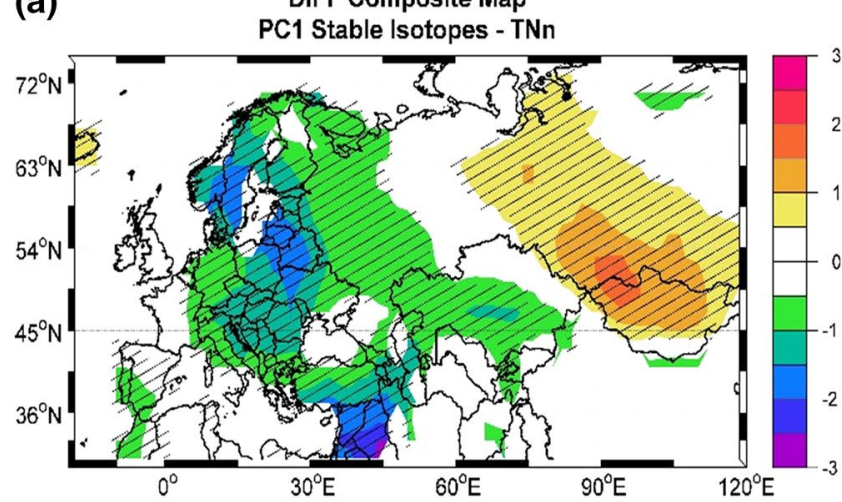

(b)

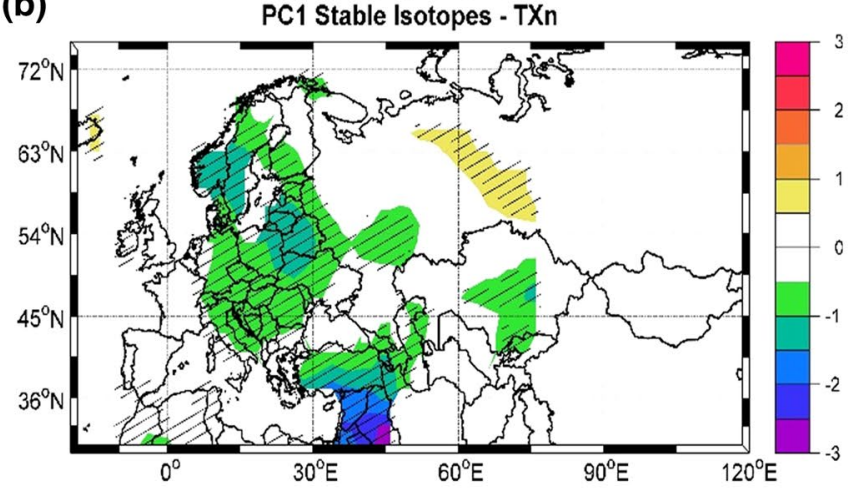

Fig. 12 The composite maps of winter a minimum value of daily minimum temperature $(\mathrm{TNn}), \mathbf{b}$ minimum value of daily maximum temperature (TXn), c maximum value of minimum daily temperature $(\mathrm{TNx})$ and $\mathbf{d}$ maximum value of maximum daily temperature (TXx), (c)

DIFF Composite Map

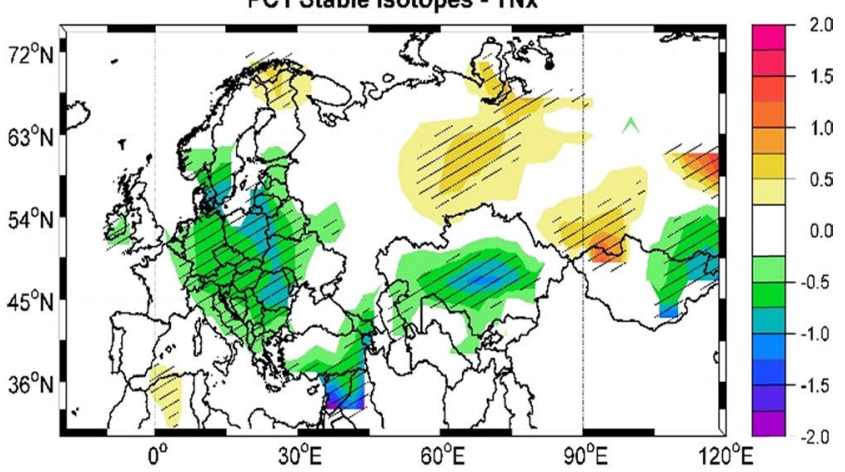

(d)

DIFF Composite Map PC1 Stable Isotopes - TXX

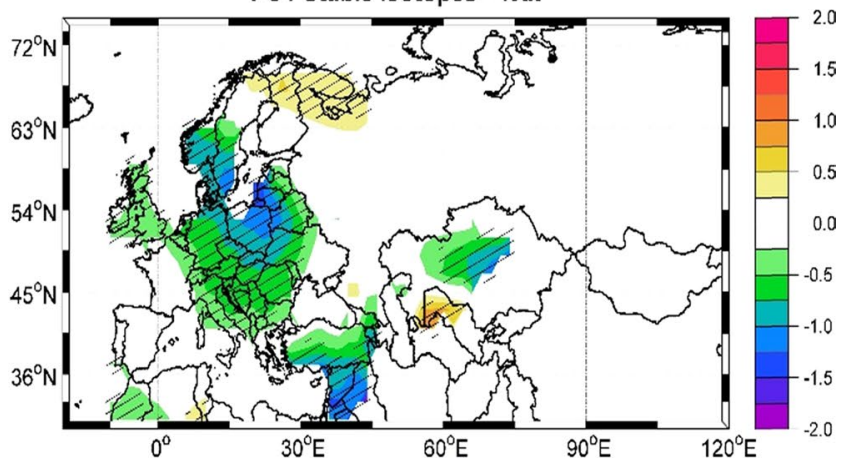

associated with ice core PC1. Period is 1901-1973. The regions where the anomalies are significant at $90 \%$ level are hatched. Units ${ }^{\circ} \mathrm{C}$ 
indices from the ECA\&D data set. The composite maps associated with ice core PC1 (not shown) are in perfect agreement with the corresponding composite maps based on HadEX2 data set (Figs. 9a, 12). Based on these maps we define extreme temperature indices by averaging the all available normalized TN10p, TNn, TNx, TXn and TXx records within the region $\left(10^{\circ} \mathrm{E}-30^{\circ} \mathrm{E} ; 40^{\circ} \mathrm{N}-55^{\circ} \mathrm{N}\right)$. In this region the anomaly of all indices are significantly $(90 \%$ level) different from zero (Figs. 9a, 12). Coherent multidecadal variability of these indices and ice core $\mathrm{PC} 1$ are detected. Opposite anomalies of TNn, TNx, TXn and TXx indices and TN10p as well as ice core PC1 are recorded during 1910-1920, 1930-1945 and 1960-1970 (Fig. 13). Less coherent variations are recorded in 1950s, when ice core PC1 shows a pronounced minimum (Fig. 13). Decadal to multidecadal variations similar to ice cores PC1 characterize the second pattern of blocking variability in the North Atlantic region (Fig. 6c).

The ice core PC1, which covers the 1300-1973 period (Fig. 14a), shows weak multicentennial but pronounced decadal to multidecadal variations. There are not unusual variations of the PC1 during recent decades. The wavelet spectrum of this time series (Fig. 14b) shows significant, but strong non-stationary oscillations, in the 10-30 years frequency interval as well as enhanced variability at 50-70 years time scales. The global spectrum (not shown) shows significant peaks at $\sim 12$ and $\sim 20$ years as well as a non-significant peak at $\sim 50$ years. Strong bi-decadal variability was identified in other proxy records from the region, like $\delta^{18} \mathrm{O}$ from northern Greenland (Masson-Delmotte et al.

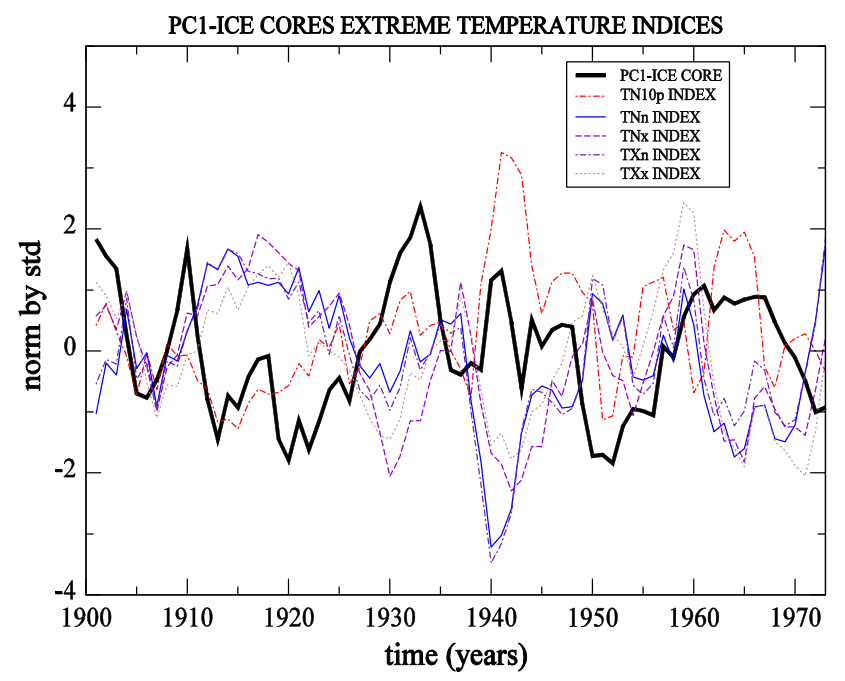

Fig. $13 \mathrm{PC} 1$ of stable isotope time series from central Greenland ice cores (thick) and the extreme temperature indices over Europe (see text for definition) (thin). The time series are linear detrended, filtered with a 5-year running mean and normalized with corresponding standard deviation. Period is 1901-1973
2015) and an accumulation records from northern Greenland (Rimbu et al. 2007).

\section{Discussion and conclusions}

Both model simulations and analysis of observational data show that decadal $\delta^{18} \mathrm{O}$ variability in central Greenland is related to distinct patterns in the frequency of atmospheric blocking and extreme temperature indices over the Eurasian continent. Enhanced blocking activity in the Atlantic-European region as well as positive anomalies in the frequency of cold events over Europe are recorded during periods characterized by positive anomalies of stable isotope $\left(\delta^{2} \mathrm{H}\right.$ and $\delta^{18} \mathrm{O}$ ) in central Greenland ice cores. A correlation analysis reveals that stable isotope from central Greenland are significantly negatively correlated with the NAO index (e.g. Vinther et al. 2010a). Consistent with these results, the negative phase of the NAO, which is related to enhanced blocking activity in the North Atlantic region (e.g. Shabbar et al. 2001), is accompanied by enhanced frequency of extreme cold events over western and central Europe (e.g. Andrade et al. 2012). However, we show here that, during the instrumental period, central Greenland stable isotope ice core records and extreme climate indices over Europe are better correlated with indices of blocking activity in the North Atlantic region than with the NAO indices at decadal to multidecadal time scales. A similar analysis applied to the five $\delta^{18} \mathrm{O}$ records from central Greenland records (sites A, B, D, E and G), described in Vinther et al. (2010a), (not shown) reveals also a higher correlation of these ice core PC1 with blocking PC2 $(r=+0.72)$ than with NAO-CRU index $(r=-0.34)$ for the 1901-1970 period.

Analysis of observational data as well as model simulation reveals that central Greenland stable isotope variability is associated with a blocking anomaly pattern similar to that of the AMO (e.g. Häkkinen et al. 2011). McLeod and Mote (2016) showed that AMO and Greenland blocking are positively correlated. Masson-Delmotte et al. (2015) show that northwestern Greenland stable oxygen isotope variability is related to a sea surface temperature (SST) pattern showing strong SST anomalies near Greenland as well as in the subtropical and tropical Atlantic (their Fig. 6a). In the Atlantic region, their SST pattern is very similar with the SST pattern associated to the second mode of North Atlantic blocking variability (Rimbu et al. 2014), which contains AMO related blocking signal. This suggests that the imprint of the AMO in the NEEM record from northwestern Greenland (Masson-Delmotte et al. 2015) is related to the blocking anomaly pattern associated with the AMO. Interestingly, the central Greenland $\delta^{18} \mathrm{O}$ index simulated with ECHAM5-wiso model shows multidecadal variations similar to those of the AMO index over the period 1960-2013. 

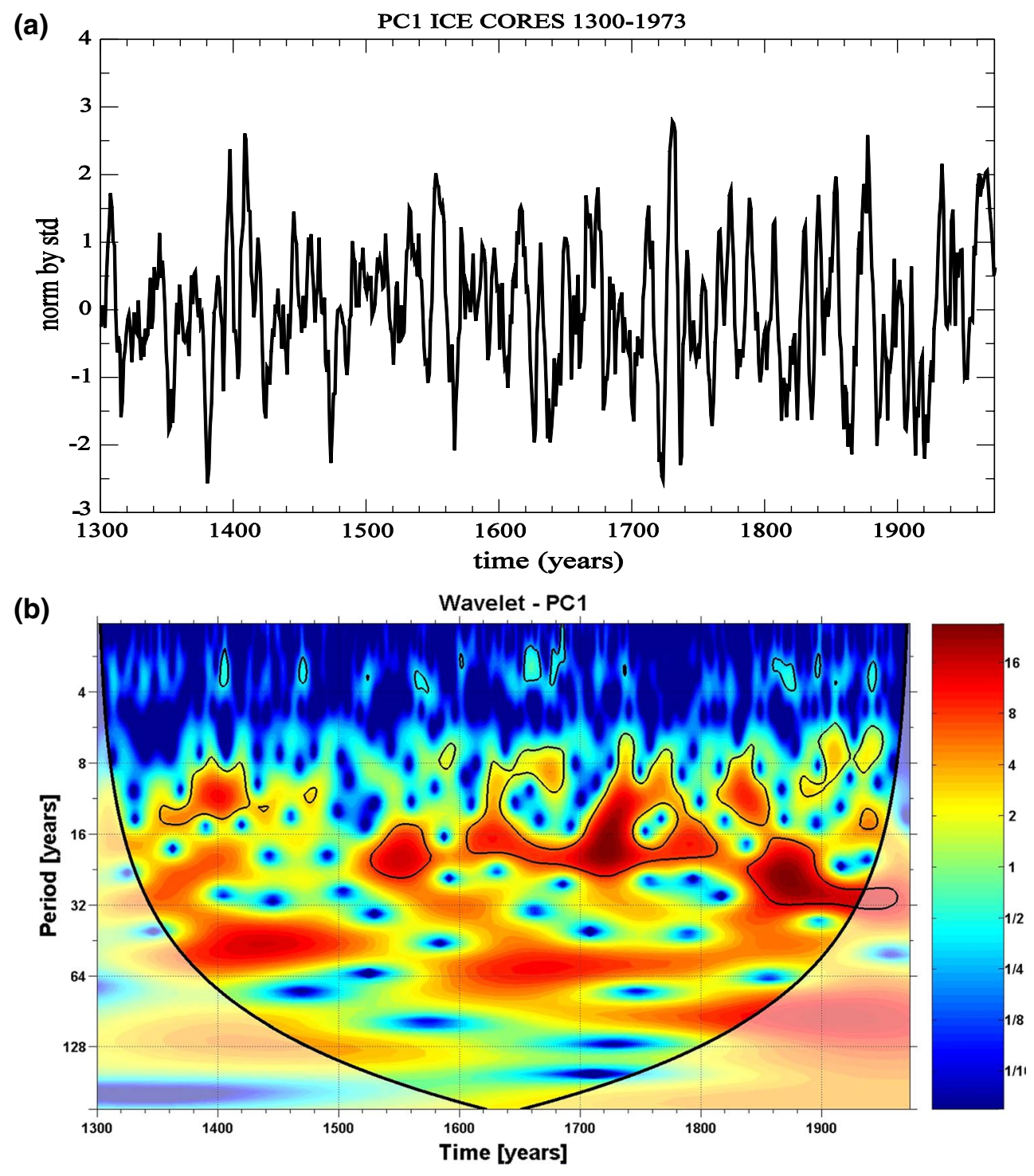

Fig. 14 a First principal component (PC1) of stable isotope ice core records for the period 1300-1973. b Wavelet spectrum of the time series represented in a. The thick black contours designate the $90 \%$

However, long-term simulations of the ECHAM5-wiso and other general circulation models which include the representation of water stable isotopes are necessary to clearly detect and understand the AMO signal in central Greenland stable isotopes variability at multidecadal time scales.

The recent strong increase in Arctic temperature leads to decrease of temperature difference between Arctic and mid-latitudes and therefore to a weaker zonal jet with larger meanders (e.g. Cohen et al. 2014). Such a polar jet structure is consistent with more persistent weather patterns (Francis and Vavrus 2012). Furthermore, Arctic warming causes the thickness of atmospheric layers to increase more to the north, such that the peaks of atmospheric ridges may elongate northward, and thus, increase the north-south significant level against red noise. The spectrum outside the cone of influence where the edge effects might be important is shown as a light shaded. Colors show power or variance

amplitude of the flow (Francis and Vavrus 2012) and therefore more extreme mid-latitude climate. Such processes could be responsible also for decadal to multidecadal variations of central Greenland ice cores and associated extreme temperatures over Europe during past periods. Long-term isotopic-enabled model simulations should be performed in order to understand the relationships between central Greenland stable isotope variability, atmospheric circulation and extreme climate variability at decadal to multidecadal time scales.

A growing body of studies, reports enhanced variability in the North Atlantic at 20-30 years time scales in model simulations (Ortega et al. 2015) as well as in observational (e.g. Dima et al. 2002) or proxy (Rimbu et al. 2007; 
Masson-Delmotte et al. 2015) data. Analysis of model simulations (e.g. Swingedouw et al. 2015 and references therein) suggests that such variability is related to the size and characteristic time of advection processes involved in the dynamics of subpolar gyre. The long-lasting impact of moderate volcanic eruptions can excite this mode of internal ocean variability (Swingedouw et al. 2015). Wavelet analysis of our central Greenland stable isotope records shows increased variability at $10-30$ years time scale. Consistent with above mentioned studies, the bi-decadal signal in our ice core records is strongly not-stationary in time suggesting a possible not regular external forcing.

Weather extremes frequently occur when atmospheric circulation patterns are persistent which tends to occur with a strong meridional wind component. This pattern is consistent with increasing activity of blocking in the Atlantic European region and its downstream effects during positive stable isotope anomalies in central Greenland ice cores. Previous studies (e.g. Trigo et al. 2004) shows that frequency of cold events over Europe increase during periods of enhanced blocking activity in the North Atlantic due to increasing advection of cold polar air masses over Europe. Recent studies show that there are also downstream effects of NAO and blocking (e.g. Sung et al. 2010). They show that persistent (several days) negative NAO events are accompanied by quasi-stationary wave trains in downstream upper levels as well as with surface eastward migrating anticyclones. The atmospheric circulation pattern associated to central Greenland decadal stable isotope variability (Fig. 9b) as well associated with extreme positive daily $\delta^{18} \mathrm{O}$ events in central Greenland in the model simulation (Fig. 10b) are consistent with this mechanism. We argue that low frequency of cold events over $\left(70^{\circ} \mathrm{E}-120^{\circ} \mathrm{E}\right.$; $50^{\circ} \mathrm{N}-70^{\circ} \mathrm{N}$ ) region as well as high frequency of such events over $\left(40^{\circ} \mathrm{E}-80^{\circ} \mathrm{E} ; 35^{\circ} \mathrm{N}-45^{\circ} \mathrm{N}\right)$ (Fig. 9a) is a consequence of high frequency of surface anticyclones that accompany persistent negative NAO or blocking events in the North Atlantic region. Analysis of daily atmospheric circulation in ECHAM5-wiso simulation confirms that, on average, high $\delta^{18} \mathrm{O}$ daily events in central Greenland are associated with a pronounced ridge over the North Atlantic as well as with a less pronounced ridge downstream over central Asia.

A recent study (Comas-Bru et al. 2016) investigates non-stationarities in the patterns of precipitation $\delta^{18} \mathrm{O}$ over Europe associated with the NAO. Such non-stationarities are due to spatial shifts of regions where NAO and precipitation $\delta^{18} \mathrm{O}$ are significantly correlated and such shifts are a consequence of different NAO and East Atlantic pattern (EA) combination. They identified regions where the NAO signal in $\delta^{18} \mathrm{O}$ field is stationary and argue that $\delta^{18} \mathrm{O}$ proxies from such regions are good predictors for NAO reconstructions. However, stable predictors for climate indices could be identified systematically through analysis of running correlation maps (Lohmann et al. 2005; Ionita et al. 2008 , 2014). Certainly, the patterns of extreme temperature indices associated with central Greenland $\delta^{18} \mathrm{O}$ variability presented here are specific to the observational period. Assuming a stationary relationship between ice core PC1 and climate extreme indices over certain regions of Europe, part of the decadal to multidecadal extreme temperature climate indices variability can be reconstructed using central Greenland stable isotope ice core records. In particular, the periodic signals detected in the ice core PC1, i.e. 10-30 and 50-70 years frequency intervals should characterize also extreme climate indices variability over parts of Europe and Asia during the last millennium and possible in the future. This implies a certain degree of predictability of extreme temperatures in these regions at decadal to multidecadal time scales.

In this study we have shown that stable isotope variability from central Greenland ice cores are strongly related to climate extreme indices variability over Eurasian continent at decadal to multidecadal time scales. The analysis could be extended to other extreme climate indices for temperature, precipitation, heat or drought. Therefore, the central Greenland ice core records may be used to put recent blocking and extreme climate variations into a long-term perspective.

Acknowledgements This study is promoted by Helmholtz funding through the Polar Regions and Coasts in the Changing Earth System (PACES) programme of the AWI. Funding by the Helmholtz Climate Initiative REKLIM is gratefully acknowledged. M. Ionita is funded through the OC3 Project-High- and low-latitude atmosphere-ocean interactions (Excellence Cluster "The Ocean in the Earth System"). We would like to acknowledge Dr. Martin Butzin for model data support and fruitful discussions. We thank the data contributors for making their data available to the public as well as the two anonymous reviewers for their constructive comments.

\section{References}

Andrade C, Leite M, Santos JA (2012) Temperature extremes in Europe: overview of their driving atmospheric patterns. Nat Hazards Earth Syst Sci 12:671-1691. doi:10.5194/ nhess-12-1671-2012

Barlow LK, Rogers JC, Serreze MC, Barry RG (1997) Aspects of climate variability in the North Atlantic sector: discussion and relation to the Greenland Ice Sheet Project 2 high-resolution isotopic signal. J Geophs Res 102(C12):26333-26344. doi:10.1029/96JC02401

Barriopedro D, García-Herrera R, Lupo AR, Hernandez E (2006) A climatology of Northern Hemisphere blocking. J Clim 19:10421063. doi:10.1175/JCLI3678.1

Butzin M, Werner M, Masson-Delmotte V, Risi C, Frankenberg C, Gribanov K, Jouzel J, Zakharov VI (2014) Variations of oxygen-18 in West Siberian precipitation during the last 50 years. Atmos Chem Phys 14:5853-5869. doi:10.5194/ acp-14-5853-2014 
Cohen J, Screen JA, Furtado JC, Barlow M, Whittleston D, Coumou D, Francis J, Dethloff K, Entekhabi D, Overland J, Jones J (2014) Recent Arctic amplification and extreme mid-latitude weather. Nat Geosci 7:627-637. doi:10.1038/NGEO2234

Comas-Bru L, McDermott F, Werner M (2016) The effect of the East Atlantic pattern on precipitation $\delta^{18} \mathrm{O}-\mathrm{NAO}$ relationship in Europe. Clim Dyn 47:2059-2069. doi:10.1007/ s00382-015-2950-1

Compo GP, Whitaker JS, Sardeshmukh PD, Matsui N, Allan RJ, Yin $\mathrm{X}$, Gleason BE, Vose RS, Rutledge G, Bessemoulin P, Brönnimann S, Brunet M, Crouthamel RI, Grant AN, Groisman PY, Jones PD, Kruk MC, Kruger AC, Marshall GJ, Magueri M, Mok HY, Nordli $\Phi$, Ross TF, Trigo RM, Wang XL, Woodruff SD, Worley SJ (2011) The twentieth century reanalysis project. Q J R Meteorol Soc 137:1-28. doi:10.1002/qj.776

Conroy JL, Cobb KM, Noone D (2013) Comparison of precipitation isotope variability across the tropical Pacific in observations and SWING2 model simulations. J Geophys Res Atmos 118:58675892. doi:10.1002/jgrd.50412

Davini P, Cagnazzo C, Gualdi S, Navarra A (2012) Bidimensional diagnostics, variability and trends of Northern Hemisphere blocking. J Clim 25:6496-6509. doi:10.1175/ JCLI-D-12-00032.1

Dee DP, Uppala SM, Simmons AJ, Berrisford P, Poli P, Kobayashi S, Andrae U, Balmaseda MA, Balsamo G, Bauer P, Bechtold P, Beljaars ACM, van de Berg L, Bidlot J, Bormann N, Delsol C, Dragani R, Fuentes M, Geer AJ, Haimberger L, Healy SB, Hersbach H, Holm EV, Isaksen L, Kallberg P, Khöler M, Matricardi M, McNally AP, Monge-Sanz BM, Mocrette J-J, Park B-K, Peubey $\mathrm{C}$, de Rosnay $\mathrm{P}$, Tavolato $\mathrm{C}$, Thèpaut J-N, Vitart $\mathrm{F}$ (2011) The ERA-Interim reanalysis: configuration and performance of the data assimilation system. Q J R Meteor Soc 137(656):553597. doi:10.1002/qj. 828

Dima N, Rimbu N, Dima I (2002) Arctic Oscillation variability generated through inter-oceans interactions. Geophys Res Lett 29(14):22-1-22-4. doi:10.1029/2002GL014717

Donat MG, Alexander LV, Yang H, Durre I, Vose R, Dunn RJH, Willett KM, Aguilar E, Brunet M, Caesar J, Hewitson B, Jack C, Klein Tank AMG, Kruger AC, Marengo J, Peterson TC, Renom M, Oria Rojas C, Rusticucci M, Salinger J, Elrayah AS, Sekele SS, Srivastava AK, Trewin B, Villarroel C, Vincent LA, Zhai P, Zhang X, Kitching S (2013) Updated analysis of temperature and precipitation extreme indices since the beginning of the twentieth century: the HadEX2 data set. J Geophys Res Atmos 118:2098-2118. doi:10.1002/jgrd.50150

Francis JA, Vavrus SJ (2012) Evidences linking Arctic amplification to extreme weather in mid-latitudes. Geopys Res Lett 39:L06801. doi:10.1029/2012GL051000

Häkkinen S, Rhines PB, Worthen DL (2011) Atmospheric blocking and Atlantic multidecadal ocean variability. Science 334:655659. doi:10.1126/science. 1205683

Hanna E, Cropper TE, Hall RJ, Cappelen J (2016) Greenland blocking index 1851-2015: a regional climate change signal. Int J Climatol. doi: $10.1002 /$ joc.4673

Haylock MR, Hofstra N, Klein Tank AMG, Klock EJ, Jones PD, New M (2008) A European daily high-resolution gridded data-set of surface temperature and precipitation. J Geophys Res Atmos 113:D20119. doi:10.1029/2008JD10201

Hurrell JW, Kushnir Y, Visbeck M, Ottersen G (2003) An overview of the North Atlantic Oscillation. In: Hurrell JW, Kushnir Y, Ottersen G, Visbeck M (eds) The North Atlantic Oscillation: climate significance and environmental impact. Geophysical monograph series, vol 134, pp 1-35

Ionita M, Lohmann G, Rimbu N (2008) Prediction of spring Elbe discharge based on stable teleconnections with global temperature and precipitation. J Clim 21:6215-6226. doi:10.1175/2008j cli2248.1

Ionita M, Dima M, Lohmann G, Scholz P, Rimbu N (2014) Predicting the June 2013 European flooding based on precipitation, soil moisture and sea level pressure. J Hydrometeorol 16:598-614. doi:10.1175/JHM-D-14-0156.1

Ionita M, Scholz P, Lohmann G, Dima M, Prange M (2016) Linkages between atmospheric blocking, sea ice export through Fram Strait and the Atlantic Meridional Overturning Circulation. Sci Rep 6:32881. doi:10.1038/srep32881

IPCC (2000) Emission scenarios: a special report of Working Group III of the Intergovernmental Panel on Climate Change. Nakicenovic, edited by: Swart R. Cambridge University Press, Cambridge

Jones PD, Jónsson T, Wheeler D (1997) Extension to the North Atlantic Oscillation using early instrumental pressure observations from Gibraltar and South-West Iceland. Int J Climatol 17:1433-1450

Karl TR, Nicholls N, Ghazi A (1999) CLIVAR/GCOS/WMO workshop on indices and indicators for climate extremes: workshop summary. Clim Change 42:3-7

Langebroek PM, Werner M, Lohmann G (2011) Climate information imprinted in oxygen-isotopic composition of precipitation in Europe. Earth Planet Sci Lett 311:144-154. doi:10.1016/j. eps1.2011.08.049

Liu C, Barnes EA (2015) Extreme moisture transport into the Arctic linked to Rossby wave breaking. J Geophys Res Atmos 120:3774-3788. doi:10.1002/2014JD022796

Lohmann G, Rimbu N, Dima M (2005) Where can the Arctic oscillation be reconstructed? Towards a reconstruction of climate modes based on stable teleconnections. Climate of the Past Discussions, European Geosciences Union (EGU), vol 1, no 1, pp 17-56

Masson-Delmotte V, Steen-Larsen HC, Ortega P, Swingedouw D, Popp T, Vinther BM, Oerter H, Sveinbjornsdottir AE, Gudlaugsdottir H, Box JE, Falourd S, Fettweis X, Gallée H, Garnier E, Gkinis V, Jouzel J, Landais A, Minster B, Paradis N, Orsi A, Risi C, Werner M, White JWC (2015) Recent changes in northwest Greenland climate documented by NEEM shallow ice core data and simulations, and implications for past temperature reconstructions. The Cryosphere 9:1481-1504. doi:10.5194/ tc-9-1481-2015

McLeod JT, Mote TL (2016) Linking interannual variability in extreme Greenland blocking episodes to the recent increase in summer melting across the Greenland ice sheet. Int J Climatol 36:1484-1499. doi:10.1002/joc.4440

Ortega P, Swingedouw D, Masson-Delmotte Risi C, Vinther B, Yiou P, Vautard R, Yoshimura K (2014) Characterizing atmospheric circulation signals in Greenland ice cores: insights from a weather regime approach. Clim Dyn 43:2585-2605. doi:10.1007/ s00382-014-2074-z

Ortega P, Mignot J, Swingedouw D, Sevellec F, Guilyardi E (2015) Reconciling two alternative mechanisms behind bi-decadal variability in the North Atlantic. Prog Oceanogr 137:237-249. doi:10.1016/j.pocean.2015.06.009

Rimbu N, Lohmann G (2010) Decadal variability in a Central Greenland high-resolution deuterium isotope record and its relationship to the frequency of daily atmospheric circulation patterns from the North Atlantic Region. J Clim 23:4608-4618. doi:10.11 75/2010JCLI3556.1

Rimbu N, Lohmann G (2011) Winter and summer blocking variability in the North Atlantic region. Evidence from long-term observational and proxy data from southwestern Greenland. Clim Past 7:543-555. doi:10.5194/cp-7-543-2011

Rimbu N, Lohmann G, Grosfeld K (2007) Northern Hemisphere atmospheric blocking in ice core accumulation records from 
northern Greenland. Geophys Res Lett 34(9):L09704. doi:10.10 29/2006GL029175

Rimbu N, Lohmann G, Ionita M (2014) Interannual to multidecadal Euro-Atlantic blocking variability during winter and its relationship with extreme low temperatures in Europe. J Geophys Res Atmos 119:13621-13636. doi:10.1002/2014JD021983

Roeckner E, Brokopf R, Esch M, Giorgetta M, Hagemann S, Kornblueh L, Manzini E, Schlese U, Schulzweida U (2006) Sensitivity of simulated climate to horizontal and vertical resolution in the ECHAM5 atmosphere model. J Clim 19:3771-3791. doi:10.1175/JCLI3824.1

Scherrer SC, Croci-Maspoli M, Schwierz C, Appenzeller C (2006) Two-dimensional indices of atmospheric blocking and their statistical relationship with winter climate patterns in the EuroAtlantic region. Int J Climatol 26:233-249. doi:10.1002/joc.1250

Shabbar A, Huang J, Higuchi K (2001) The relationship between the wintertime North Atlantic Oscillation and blocking episodes in the North Atlantic. Int J Climatol 21:355-369. doi:10.1002/ joc. 612

Silmann J, Croci-Maspoli M, Kallache M, Katz RW (2011) Extreme cold winter temperatures in Europe under the influence of North Atlantic atmospheric blocking. J Clim 24:5899-5913. doi:10.11 75/2011JCLI4075.1

Sung MK, Lim GH, Kug JS (2010) Phase asymmetric downstream development of the North Atlantic Oscillation and its impact on the East Asian winter monsoon. J Geophys Res 115:D9. doi:10.1 029/2009JD013153

Swingedouw D, Ortega P, Mignot J, Guilyardi E, Masson-Delmotte V, Butler PG, Khodri M, Sèfèrian R (2015) Bidecadal North
Atlantic ocean circulation variability controlled by timing of volcanic eruptions. Nat Commun 6:6545. doi:10.1038/ncomms7545

Tibaldi S, Molteni F (1990) On the operational predictability of blocking. Tellus A 42:343-365. doi:10.1034/j.1600-0870.1990. t01-2-00003.x

Torrence C, Compo GP (1998) A practical guide to wavelet analysis. Bull Am Meteorl Soc 79:61-78. doi:10.1175/1520-0477

Trigo RM, Trigo IF, DaCamara CC, Osborn TJ (2004) Climate impact of the European winter blocking episodes from the NCEP/NCAR reanalyses. Clim Dyn 23(1):17-28. doi:10.1007/ s00382-004-0410-4

Vinther BM, Jones PD, Briffa KR, Clausen HB, Andersen KK, DahlJensen D, Johnsen SJ (2010a) Climatic signals in multiple high resolved stable isotope records from Greenland. Quat Sci Rev 29:522-538. doi:10.1016/j.quascirev.2009.11.002

Vinther BM et al (2010b) CRETE_1974 high resolution stable oxygen isotope record. doi:10.1594/PANGAEA.786356

Vinther BM et al (2010c) (Fig. 20) GRIP high resolution stable oxygen isotope record. doi:10.1594/PANGAEA.786354

von Storch H, Zwiers FW (1999) Statistical analysis in climate research. Cambridge University Press, Cambridge

Werner M, Heimann M (2002) Modelling interannual variability of water isotopes in Greenland and Antarctica. J Geophys Res 107(D1)4001:ACL 1-13. doi:10.1029/2001JD900253

Werner M, Langebroek PM, Carlsen T, Herold M, Lohmann G (2011) Stable water isotopes in the ECHAM5 general circulation model: toward high-resolution isotope modeling on a global scale. J Geophys Res 116:D15109. doi:10.1029/2011jd015681 